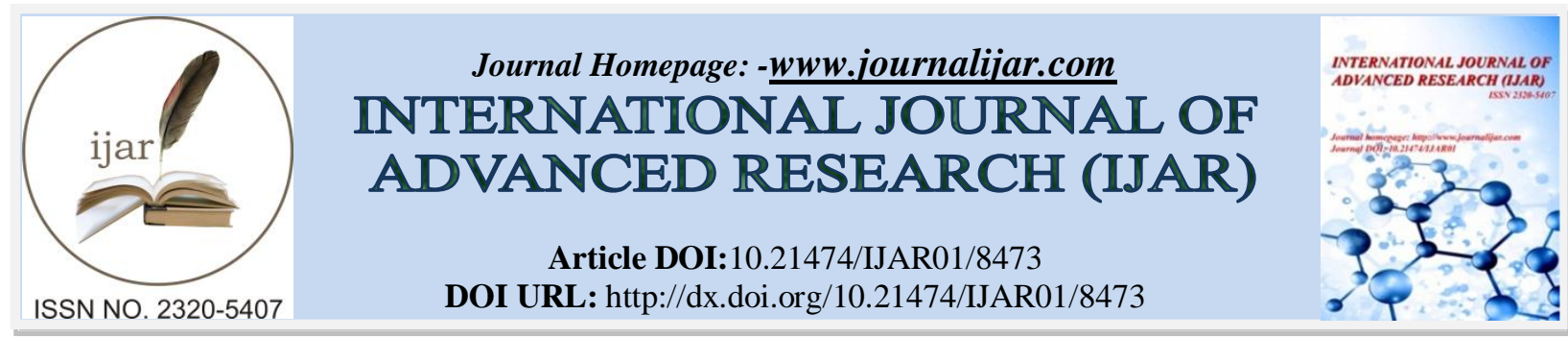

RESEARCH ARTICLE

\title{
SWOT ANALYSIS TO DETERMINE DEVELOPMENT STRATEGIES AT NAVAL TECHNOLOGYCOLLEGES(A CASE STUDY).
}

AyipRivaiPrabowo, ZaenalFanani and Moeljadi.

University of Brawijaya, Malang, East Java, 65145, Indonesia.

\section{Manuscript Info}

Manuscript History

Received: 02 December 2018

Final Accepted: 04 January 2019

Published: February 2019

Key words:-

SWOT Analysis, Naval Technology

Colleges, Development Strategy.

\begin{abstract}
The organization of higher education conducted by the navy and has received recognition from the government. This opportunity is well utilized by naval technology colleges to continue to develop in service and lead to very high competition. To deal with various the problems mentioned above, naval technology high schools must have a strategy that is appropriate to deal with it. The purpose of this study is to provide an analysis of the development of naval technology Colleges strategies in facing the demands of universities. The method used in this study uses the SWOT analysis method. The SWOT analysis is used to identify criteria for strengths, weaknesses, opportunities, and threats that exist in naval technology colleges. The results of the study indicate that Human Resources issues are crucial in increasing the competitiveness of universities. Quality of lecturers and the effectiveness of education staff is the main thing to increase the power competitiveness of universities, also in terms of increasing the competitiveness of college graduates
\end{abstract}

Copy Right, IJAR, 2019,. All rights reserved.

\section{Introduction:-}

The National Education System Law, states that education is shared responsibility between the government, parents and the community. This means the community has the right to establish and manage higher education in accordance withapplicable laws and regulations. Law Number 12 of 2012, concerning Higher Education, which requires universities Highly accredited both institutions and study programs that they care for. This matter encourages Naval technology Colleges to strive to maintain and evenimprove its accreditation status.

Certainly, it is not an easy thing for naval technology high schools to be able to maintain the value of accreditation and ensure the continuity of learning and create quality student graduates, even though in full all funding is supported by the navy. however, the limited human resources of lecturers, staff and education staff are among the few weaknesses that must be sought for a solution.

The most powerful force to meet the era of globalization is strategic acquisition (Bamousa, 2016). The method used in answering problems that exist in universities, especially naval technology colleges, is to use SWOT analysis. Where the SWOT analysis is very effective in determining the influence of internal and external factors. The implementation of a SWOT analysis must be considered not only as an input for strategic planning so that it cannot be used alone (Orr, 2013 ).

Corresponding Author:-AyipRivaiPrabowo.

Address:-University of Brawijaya, Malang, East Java, 65145, Indonesia. 
This study also refers to previous studies such as research with titles Study the Importance of SWOT Analysis on ERP Implementation (Wanare, 2014), The Strengths, Weaknesses, Opportunitiesand Threats (SWOT) Analysis of Mycobacterium tuberculosis: A Systematic Review (Babalola, 2015), Tourism Development Strategies, SWOT analysis and improvement of Albania's image (Vladi, 2014), Role of Women Entrepreneurs in India: A SWOT Analysis (Singh, 2014), A Quick Guide to the SWOT Analysis Department of Field Activities (M, 2017), SWOT Analysis in Strategic Management and a Sample Application in Public (Tuncay, 2-015), SWOT Analysis Of Online Shopping Models (Kumar \&Dr.J.Srikanth, 2017), Organized retail in India - Drivers facilitator and SWOT analysis (Jhamb\&Kiran, 2011).

This research is divided into four phases, phase 1 introduction, step 2 material and methodology, step 3 results and discussion and final stage are conclusions and suggestions.

\section{Material/Methodology:-}

The concept of Strength, Weakness, Opportunity, Threat (SWOT) Analysis:-

By implementing a SWOT analysis an educational institution will be able to examine the factors that can influence its institutional performance for future development (Wahyuningtias, Sudarmiatin, \&Indrawati, 2016 ). A SWOT analysis is the most common technique that can be used to analyze strategic cases. This SWOT analysis will help organizations and individuals about systematic and comprehensive ways of thinking by diagnosing factors (Salar\&Salar, (2014 ). SWOT is a tool that is often used to analyze internal and external environments to achieve systematic approaches and support for decision situations. SWOT is an acronym of strength (S), weakness (W), opportunity (O) and threat $(\mathrm{T})$. The first two factors (strengths and weaknesses) are related to internal organizational factors, while opportunities and threats cover the broader context or environment in which the entity operates.

Strategic planning is wholly owned by the organization in defining its strategic plan (Nair \&P.Amresh, 2016). Internal and external factors are referred to as strategic factors and are summarized in the SWOT analysis. Strengths and weaknesses are factors in the system that allow and prevent the organization from achieving its objectives. Opportunities and threats are considered as external factors that facilitate and limit the organization in achieving its own goals. SWOT analysis shows the right strategies in four categories SO, ST, WO, and WT. The strategy identified as SO involves taking advantage of opportunities using existing strengths. ST is a strategy related to the use of force to eliminate or reduce the effects of threats. Likewise, the WO strategy seeks to benefit from the opportunities presented by external environmental factors by paying attention to its weaknesses. The fourth and final is WT, where the organization tries to reduce the impact of its threat by considering its weaknesses.

Table 2.1:-Matrix SWOT Analysis

\begin{tabular}{|c|c|c|}
\hline $\begin{array}{c}\text { INTERNAL/EXTERNAL } \\
\text { FAKTOR }\end{array}$ & $\begin{array}{c}\text { STRENGTH(S) } \\
\text { (Maximal) }\end{array}$ & $\begin{array}{c}\text { WEAKNESS (W) } \\
\text { (Minimal) }\end{array}$ \\
\hline $\begin{array}{c}\text { OPPORTUNITIES (O) } \\
\text { (maximal) }\end{array}$ & $\begin{array}{c}\text { S-OStrategy } \\
\text { (Maximal-Maximal) }\end{array}$ & $\begin{array}{c}\text { W-TStrategy } \\
\text { (Minimal-Minimal) }\end{array}$ \\
\hline $\begin{array}{c}\text { THREATS (T) } \\
\text { (Minimal) }\end{array}$ & $\begin{array}{c}\text { S-TStrategy } \\
\text { (Maximal-Minimal) }\end{array}$ & $\begin{array}{c}\text { W-OStrategy } \\
\text { (Minimal-Maximal) }\end{array}$ \\
\hline
\end{tabular}

\section{Strategy Management:-}

David (2011) defines strategy as a comprehensive plan to achieve organizational goals. Not only achieving goals but also maintaining the survival of the organization in the environment in which the organization operates its activities. The strategy is a potential action that requires management decisions large sums and company resources. Influencing strategy the company's long-term development, usually the next five years, accordingly future-oriented. Whereas according to Chandler in Rangkuti (2013) mention that the strategy is the long-term goal of the company, as well as utilization and allocation of important resources to achieve these goals. Kuncoro (2006) states strategy as a process, which includes a number of stages interrelated and sequential. The main stages of the management 
strategy process generally include situation analysis, strategy formulation, strategy implementation, and performance evaluation. The strategy is also contextual, must be fitted with core competencies and challenges faced. So it can be concluded that strategy is a choice about actions carried out by the organization to achieve its objectives and to achieve excellence competitive. To be more effective in implementing strategies, the approach is unique and that most in accordance with the conditions of internal and external factors and very important challenges (Baroto, Arvand, \& Ahmad, 2014).

\section{Competitive Advantage:-}

Competitive advantage is the superiority possessed by the organization or company, where its superiority is used to compete and competewithother organizations or companies, to get something. A factor is said to have a competitive advantage when these factors have something they don't have competitors, doing something better than other actors, or being able to do something not able to be done by other factors (Kuncoro. 2006). Example: the company markets products by utilizing customer-focused services in accordance with the value superior company in competing with competing companies. Company superiority can be generated from the company's ability to utilize various resources and its capabilities as a strategic asset. The success of managing this strategic asset will determine the distinctive advantages of a company that can create differential positions compared to competitors. If competitive advantage is based on structural characteristics, such as market forces, economies of scale, or product lines, the emphasis is currently on business to deliver superior value consistently becomes the focus of its customers.

For doing this then competitive advantage is not just a function in the role company but more dependent on the company's ability to change radically. Then there are four basic needs for resources that must be met within achieve sustainable competitive advantages, namely:-

1. Value, with added value owned, will increase competitive advantage company.

2. The uniqueness of similar companies and potential competitors. If a company has its own uniqueness, it will increase the competitive advantage it has among competitors.

3. It cannot be imitated perfectly. Companies with products that cannot be replicated perfectly competing have added value in achieving excellence compete,

4. There must be no similar strategy that can replace resources. If not there strategies that can replace resources then a company will achieve own competitive advantage.

The main pillar of national competitiveness is human capital or human capital, the second is technological innovation. Low HR problems causing the development process to run less smoothly because it is not supported by adequate labor productivity and quality. HR productivity level is one of the benchmarks for quality of HR, the higher the productivity of HR, the better the quality. Vice versa. Likewise in higher education studies, problems HR is a crucial thing in increasing the competitiveness of universities. Quality lecturers and the effectiveness of education staff are the main things to improve the competitiveness of universities, also in terms of increasing the competitiveness of college graduates because the quality of college graduates is one indicator to assess strength the competitiveness of a college. The problem that occurs is the lack of HR quality at College. Less commitment from lecturers and education staff is key the main is the lack of competence of college graduates, in addition to curriculum and facilities problems infrastructure. Trimming or changing curriculum in most universities the cause of the lack of quality teaching lecturers. the competitive advantage of an organization is that it depends on the purpose of sharing existing resources and knowledge (Hana, 2013 ).

\section{Naval Technology Colleges:-}

STTAL as the Indonesian Navy's educational institution has a goal to print a character of the Navy soldiers, have the spirit of Pancasila, master the science and technology of the marine field to meet the interests of national defense and national competitiveness. Naval Technology Colleges graduates must have professionalism in the field of marine science and technology to supervise organizations and defense equipment with the current high-tech Indonesian Navy. The standard is set to obtain scientific (academic) abilities and expertise (profession) from the strata of officers (S-1, S-2) and non-commissioned officers (D-3). For that professionalism of soldiers can meet cognitive standards with academic (responsive), psychomotor with adaptability and effective with mental or personality.

At this time Naval Technology Colleges is in the stage of submitting the fulfillment of laboratory facilities and equipment that support education in each study program to gradually adjust the priority scale and available budget. 
Naval Technology Colleges as a state university under the Ministry of Research, Technology and Higher Education also carries out the function of the Tri Dharma of Higher Education, which organizes educational, research and community service activities. Research is the main task of the lecturer in addition to carrying out community teaching and service. Academically research is part of the development of science. The research assignments carried out can be in the form of producing research works, adapting/translating scientific books, editing/editing scientific works, making technological designs and works, and designing artwork. Based on Law Number 18 of 2002, Naval Technology Colleges is an institution that carries out institutional functions in conducting research so that it can improve the ability of Lecturers in teaching. This will improve the quality of learning materials always follow the era.

Naval Technology Colleges as the executor of management standards must carry out the preparation of curriculum and learning plans in each course. In Law No. 12 of 2012 concerning Higher Education guarantees curriculum development is the right of universities. The curriculum is a programmed strategy of Naval Technology Colleges to produce graduates who have defined abilities. Ability in question is the achievement of learning mastery of knowledge, workability, attitudes, and values as well as authority and responsibility.

Organizations that exist today based on the List of Personnel Arrangements in 2015 that the number of officers currently is 90 personnel, non-commissioned officers 74 personnel, enlisted 19 personnel and 6 civil servants. At this time the number of officers at Naval Technology Colleges was greater than the number of non-commissioned officers and enlisted officers so that the number of officers in running educational operations has an excessive burden.

\section{Research Methodology:-}

To solve problems in the observed research, steps are needed and determined to describe the approach and model of the problem. The steps taken are:

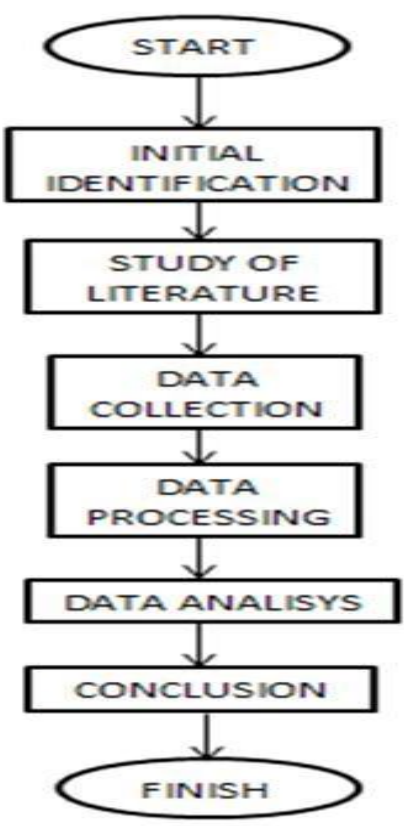

Figure 2.2:-Research Methodology Flowchart.

\section{Result And Discussion:-}

A SWOT analysis is an analysis that emphasizes four aspects, namely Strength, Weakness, Opportunity, and Threat. This SWOT analysis will identify internal and external factors in developing Naval Technology Colleges so that potentials can be developed in the future and overcome weaknesses - weaknesses that exist. From the internal side, it can be seen the strengths or weaknesses possessed for the development of naval technology Colleges strategies, 
while from the external side there will be seen opportunities and threats from outside the development of naval high school technology, after identifying these factors formulation of the strategy using methods SWOT.

Referring to the goals and objectives of evaluating and implementing the SWOT analysis, it will be known what are the strengths and weaknesses and strategies for developing Naval technology Colleges and the opportunities that support the development of Naval technology Colleges and threats that will be faced in the development.

\section{Strength:-}

The definition of Strength in a SWOT analysis is the strength or strength that exists in a company or organization that affects the strategic decision-making process. Strength found in the development of the Naval technology Colleges is the increasing state budget for defense, marine-oriented government policies.

\section{Weakness:-}

The definition of Weakness in a SWOT analysis is a weakness that exists in a company or organization that influences strategic decision-making processes. The weakness that is found in the development of Naval Technology Colleges is the absence of an independent internal accreditation institution, lack of library support facilities and research institutions and community services that are not yet in accordance with university standards.

\section{Opportunities:-}

The definition of opportunity in a SWOT analysis is the opportunity that exists in a company or organization that influences strategic decision-making processes, which is an opportunity found in the development of Naval technology Colleges is the cost of research assistance from the government, the existence of research institutions that utilize universities as research implementers military.

\section{Threats:-}

The definition of Threat in a SWOT analysis is the threat that exists in a company or organization that influences the strategic decision-making process that poses a threat to the development of Naval technology Colleges is the existence of universities that open defense study programs, limited research costs.

The SWOT analysis data was obtained through observations on the object of research on the basis of the existing theory and then proceeded with the interview on the object of assessment after questioning was carried out on the stakeholders in the Naval technology Colleges. In analyzing with the SWOT method approach, stages of identification of aspects and criteria are carried out which are the variables in the study. The research aspects and criteria identified were influential variables and interacted with the Naval technology Colleges development strategy.

Variable Identification Stages carried out by conducting literature studies and conducting interviews with Expert. From the process of understanding the study of literature and conducting interviews with the Expert, there are influential variables. The following is the identification of the variables shown in table 3.1

Table 3.1:-matrix SWOT

\begin{tabular}{|l|l|}
\hline \multicolumn{1}{|c|}{ Strength } & \multicolumn{1}{c|}{ Opportunity } \\
\hline $\begin{array}{l}\text { 1. an increased defense budget } \\
\text { 2. marine-oriented government policy }\end{array}$ & $\begin{array}{l}\text { 1. a lot of research from government } \\
\text { institutions } \\
\text { 2. the existence of research } \\
\text { institutions that utilize universities as } \\
\text { military research implementers. }\end{array}$ \\
\hline $\begin{array}{l}\text { Weakness } \\
\text { institution }\end{array}$ & $\begin{array}{l}\text { Threat } \\
\text { 2. library supporting facilities are } \\
\text { lacking } \\
\text { 3. research institutions and community } \\
\text { services that are not university-based } \\
\text { according to university standards }\end{array}$ \\
\hline
\end{tabular}

Based on data on the strengths, weaknesses, opportunities and threats that have been obtained after developing a strategic approach as follows Strenght - Opportunities use existing forces to create opportunities, Strength - Threats 
uses existing strengths to avoid and eliminate threats - threats that exist, Weakness - Opportunities eliminate weaknesses that exist to create opportunities, Weakness - Threat eliminates weaknesses in order to avoid threats. The strategic approach is like table 3.2 below

Table 3.2:-strategy approach matrix

\begin{tabular}{|c|c|c|}
\hline $\mathrm{X}$ & $\mathbf{S}$ & $\mathbf{W}$ \\
\hline & Strategy S-O & Strategy $\mathrm{W}-\mathrm{O}$ \\
\hline $\mathbf{O}$ & $\begin{array}{l}\text { 1. improve the quality of human } \\
\text { resources in the field of research. } \\
\text { 2. making applied military research }\end{array}$ & $\begin{array}{l}\text { 1. carry out routine internal checks } \\
\text { 2. repairing library facilities by } \\
\text { cooperating with government } \\
\text { institutions } \\
\text { 3. make research and community } \\
\text { service standards in accordance } \\
\text { with university standards. }\end{array}$ \\
\hline & $\begin{array}{c}\text { Strategy S-T } \\
\end{array}$ & Strategy $\mathbf{W}-\mathrm{T}$ \\
\hline $\mathbf{T}$ & $\begin{array}{l}\text { 1. strengthening academic and research } \\
\text { fields } \\
\text { 2. cooperating with government } \\
\text { institutions for marine research }\end{array}$ & $\begin{array}{l}\text { 1. strengthen the quality of internal } \\
\text { education } \\
2 \text {. In collaboration with government } \\
\text { institutions in an effort to strengthen } \\
\text { the research field. }\end{array}$ \\
\hline
\end{tabular}

The SWOT strategy approach consists of 4 categories consisting of strategy I (Strength-Opportunity), strategy II (Weakness-Opportunity), strategy III (Strength-Threat), strategy IV (Weakness-Threat). The strategy I have 2 strategies. strategy II there are 2 strategies. Strategy III has 3 strategies. Strategy IV has 2 strategies. The strategies mentioned above are grouped or sorted from Strength-Opportunity in numbers 1 to 2, Weakness-Opportunity in numbers 3 to 5, Strength-Threat numbers 6 to 7, Weakness-Threats numbers 8 to 9, according to table 3.3 symbols and strategies.

Table 3.3:-symbols and strategies

\begin{tabular}{|c|l|c|}
\hline No & \multicolumn{1}{|c|}{ Strategy } & Symbol \\
\hline 1 & improve the quality of human resources in the field of research. & $(\mathrm{SO}) 1$ \\
\hline 2 & making applied military research & $(\mathrm{SO} 2$ \\
\hline 3 & carry out routine internal checks & $(\mathrm{WO}) 1$ \\
\hline 4 & $\begin{array}{l}\text { repairing library facilities by cooperating with government } \\
\text { institutions }\end{array}$ & $(\mathrm{WO} 2$ \\
\hline 5 & $\begin{array}{l}\text { make research and community service standards in accordance } \\
\text { with university standards. }\end{array}$ & $(\mathrm{WO}) 3$ \\
\hline 6 & strengthening academic and research fields & $(\mathrm{ST}) 1$ \\
\hline 7 & cooperating with government institutions for marine research & (ST)2 \\
\hline 8 & strengthen the quality of internal education & $(\mathrm{WT}) 1$ \\
\hline 9 & $\begin{array}{l}\text { In collaboration with government institutions in an effort to } \\
\text { strengthen the research field. }\end{array}$ & (WT)2 \\
\hline
\end{tabular}

Based on the SWOT analysis, the total strategies that have been formulated are the nine sub-strategies that determine the Naval technology Colleges development strategy to become a reliable defense field university.Based on the SWOT analysis, the priority strategy for developing Naval technology Colleges is:-

1. improve the quality of human resources in the field of research.

2. making applied military research

3. carry out routine internal checks

4. repairing library facilities by cooperating with government institutions

5. make research and community service standards in accordance with university standards.

6. strengthening academic and research fields

7. cooperating with government institutions for marine research

8. strengthen the quality of internal education

9. In collaboration with government institutions in an effort to strengthen the research field. 
10. For the next in order to sort the priorities in doing with several other methods.

\section{Conclusion:-}

To develop Naval technology Colleges, it is necessary to increase the professionalism of soldiers in the fields of science and technology to increase the quantity and quality of facilities supporting complete education in stages according to the priority scale adjusting the available budget by means of regulation, cooperation, coordination and socialization to relevant stakeholders so as to support learning and practicum optimally.

Great limitations can be overcome by collaborating with government institutions so that the maritime research can be carried out properly.

\section{References:-}

1. Babalola, M. O. (2015). The Strengths, Weaknesses, Opportunities, and Threats (SWOT) Analysis of Mycobacterium tuberculosis: A Systematic Review. Journal of Tuberculosis Research, 184-205.

2. Bamousa, W. (2016). FedEx SWOT Analysis. International Journal of Scientific \& Engineering Research, 728735.

3. Baroto, M. B., Arvand, N., \& Ahmad, F. S. (2014). Effective Strategy Implementation. Journal of Advanced Management Science, 50-54.

4. Hana, U. (2013 ). Competitive Advantage Achievement through Innovation and Knowledge. Journal of Competitiveness, 82-96.

5. Jhamb, D., \&Kiran, R. (2011). Organized retail in India - Drivers facilitator and SWOT analysis. Asian Journal of Management Research, 264-273.

6. Kumar, R. R., \&Dr.J.Srikanth. (2017). SWOT Analysis Of Online Shopping Models. Organization India Technical Research, 28-31.

7. M, M. (2017). A Quick Guide to the SWOT Analysis Departement of Field Activities. Accreditation Council for Graduate Medical Education (ACGME), 1-4.

8. Nair, C., \&P.Amresh. (2016). Development of Strategic Plan for Hotel Industries through Swot Analysis. SSRG International Journal of Mechanical Engineering ( SSRG - IJME ), 6-10.

9. Orr, B. (2013 ). Conducting a SWOT Analysis for Program Improvement. US-China Education Review A, 381384.

10. Salar, M., \&Salar, O. ((2014). Determining the pros and cons of franchising by using swot analysis. Procedia Social and Behavioral Sciences, $515-519$.

11. Singh, A. (2014). Role of Women Entrepreneurs in India: A SWOT Analysis. International Journal of Management and International Business Studies., 231-238.

12. Tuncay, M. (2-015). SWOT Analysis in Strategic Management and a sample Application in Public. Munich Personal RePEc Archive, 1-22.

13. Vladi, E. (2014). Tourism Development Strategies, SWOT analysis and improvement of Albania"s image. European Journal of Sustainable Development, 167-178.

14. Wahyuningtias, C. N., Sudarmiatin, \&Indrawati, A. (2016 ). SWOT Analysis for Determining Marketing Strategy at the Primagama Courses. IOSR Journal of Business and Management (IOSR-JBM), 38-46.

15. Wanare, D. R. (2014). Study the Importance of SWOT Analysis on ERP Implementation. International Journal of Management and Social Sciences Research (IJMSSR), 33-36. 